Acta Theriologica 38 (3): 245 - 251, 1993.

PL ISSN $0001-7051$

\title{
Diet of wolves in the Bieszczady Mountains, Poland
}

\author{
Wojciech SMIETANA* and Agata KLIMEK
}

\begin{abstract}
Smietana W. and Klimek A. 1993. Diet of wolves in the Bieszczady Mountains, Poland. Acta theriol. 38: $245-251$

The diet of wolves Canis lupus Linnaeus, 1758 was studied from October 1989 to November 1992 in the Bieszczady Mountains, southeastern Poland. A total of 221 wolf scats were collected and analyzed to determine the prey species consumed by wolves in each season. Cervids (red and roe deer) obviously predominated in wolf diet and consisted from $65 \%$ of winter biomass to $96 \%$ of summer biomass consumed. The red deer made up approximately $95 \%$ and roe deer only $5 \%$ of total cervid biomass consumed. During summer deer fawns made up $28 \%$ of total cervid biomass consumed. The wild boar constituted more significant food only during winter $-17 \%$ of biomass eaten. Among wild boars, piglets were selected and made up $66 \%$ of total wild boar biomass consumed during winter. Domestic livestock represented more significant food in winter (16\% of biomass eaten) and was consumed as carrion laid out by hunters to bait wolves. Other food categories as hares, voles and insectivores played a negligible part in the wolf diet. Spring, summer and autumn diet were little diversified. Only winter diet differed significantly from other seasons for the presence of wild boar and cervids.
\end{abstract}

Department of Wildlife Research, Institute of Environmental Biology, Jagiellonian University, Ingardena 6, 30-060 Kraków, Poland

Key words: Canis lupus, food habits, Carpathian Mountains, Poland

\section{Introduction}

Most of studies on the feeding ecology of the wolf Canis lupus Linnaeus, 1758 were carried out in the North America (e.g. Fuller and Keith 1980, Fritts and Mech 1981, Ballard et al. 1987, Hayes et al. 1991). Due to extinction of the wolf in most of its original range there is relatively little information available on feeding habits of this predator in Europe. In the southern Europe (Italy, Spain) wolves often depend on domestic livestock (Salvador and Abad 1987, Merigi et al. 1991) and in Fenoscandia wolves depend on semidomesticated reindeer (Bjarvall 1983, Nieminen and Leppaluoto 1988). Several papers on feeding ecology of wolves in the Central Europe have been published recently (Sumiński and Filipiak 1977, Brtek and Voskar 1987, Leśniewicz and Perzanowski 1989, Jędrzejewski et al. 1992). This paper describe wolf diet in the Bieszczady Mountains, Poland.

\footnotetext{
"Present address: Institute of Nature Conservation, Polish Academy of Science, Lubicz 46, 31-512 Kraków, Poland
} 


\section{Study area}

The study was conducted in the Bieszczady Mts (a range within Carpathian Mts) within forest administrative districts: Baligród, Cisna, Komańcza, Lutowiska, Stuposiany, Wetlina and the Bieszczady National Park. The area is ca $1000 \mathrm{~km}^{2}$. The highest elevation is $1346 \mathrm{~m}$ a.s.l. About $70 \%$ of the area is covered by forest. Beech Fagus silvatica is the dominant tree species and other important trees are the fir Abies alba, spruce Picea excelsa, alder Alnus incana, and the pine Pinus silvestris. The zone elevated over $1150 \mathrm{~m}$ a.s.l. is covered by meadows with Vaccinium myrtillus and variety of grasses.

Average annual temperature of air is $4.9^{\circ} \mathrm{C}$. Annual precipitation is $800-1200 \mathrm{~mm}$. Snow cover persists for $4-5$ months and its thickness may exceed $1.5 \mathrm{~m}$ (Michna and Paczos 1972).

Apart from wolves, there are also other large predators, such as the lynx Lynx lynx and the brown bear Ursus arctos. The ungulates living in the study area include the red deer Cervus elaphus, roe deer Capreolus capreolus, wild boar Sus scrofa and the European bison Bison bonasus. Recently a few individuals of the elk Alces alces were also reported from this area.

\section{Materials and methods}

Wolf diet was determined by analysis of 221 scats collected between October 1989 and November 1992 during penetration of a network of forest roads and paths. Additionally, during winters scats were found near prey carcasses or on wolf tracks followed. Each scat was placed in a paper bag and labelled with the date and location.

In the laboratory scats were oven dried at $60^{\circ} \mathrm{C}$ for 24 hours, then stored in a dry place. Next, they were soaked in a water with detergents. After 12 hours, samples were washed on a sieve made of $0.5 \mathrm{~mm}$ meshes.

Prey remains found in scats were identified on the basis of microscopic analysis of hairs according to the key by Dziurdzik (1973). Small mammals were frequently identified by teeth and bones according to the key by Pucek (1984). Macroscopic comparison of hairs of prey to reference collections was used in discrimination of age classes among ungulates.

Mean percent volume (V\%) of each food items was calculated for spring (1 April - 31 May), summer (1 June - 30 September), autumn (1 October - 30 November) and winter (1 December - 31 March). For that calculation it was necessary to estimate visually the relative volume (V) of remains of each food items (volume of a given item/total volume of every items) in scats that contained more then one food species (5.4\% of total number of scats). The sum of all relative volumes of food remains was always 1.0 for each scat. We chose that method of dietary comparison because uncommon prey are often overestimated when "frequency of occurrence" techniques are used (Weaver and Hoffman 1979).

Seasonal differences of sum of relative volumes (sumV) of different prey categories (cervids, wild boar, livestock, other) were tested for significance by $\chi^{2}$-test.

To reconstruct the wolf diet the biomass consumed by wolves of particular prey types was estimated. Biomass eaten of a given prey type per wolf scat was calculated from experimentally derived regression equation (Floyd et al. 1978):

$$
y=0.38+0.02 x \quad\left(r^{2}=0.97\right)
$$

where $y$ is the $\mathrm{kg}$ of prey per collectible (firm consistency) wolf scat, and $x$, the average body mass $(\mathrm{kg}$ ) of an individual of a given prey type. Total biomass consumed (B) of a given prey type in each season was calculated:

$$
\mathrm{B}_{\mathrm{i}}=y_{\mathrm{i}} \operatorname{sumV}_{\mathrm{i}}
$$


and is expressed in percentages (B\%) of total biomass consumed in particular seasons. Average body mass of species identified in wolf scats taken from literature were used in these calculations (Table 1). Calculations were made for each season and were refined by considering age ratio of cervids and wild boar. Usually it was possible to classify hair from cervids in scats collection from summer as either fawn or adult. In summer scats with cervids remains which could not be distinguished as fawn or adult, it was assumed for biomass consumed calculation that the ratio of juvenile remains to adult remains was as in the identified samples. Furthermore, since hair of roe deer cannot be distinguished from those of red deer (Dziurdzik 1973), average body mass used for cervids was based on relative proportion of roe and red deer dew claws found in wolf scats (it was assumed that ratio of scats containing roe and red deer dew claws represent ratio of roe and red deer number in wolf diet). Average body mass of red deer in the spring, autumn and winter diet was calculated using known fawn (1) : adult hind (1.3) : adult stag (0.7) ratio among red deer killed by wolves during winters 1988 - 1991 in the study area (Bobek et al. 1992b). (Average biomass of adult red deer in summer diet was calculated using adult hind : adult stag ratio). The piglet and adult wild boars remains were distinguishable in every seasons. However, all scats with wild boar remains could not be distinguished as piglets or adults. It was assumed that the ratio of piglets remains to adult remains was the same in the unidentified samples as in the identified samples. It was also assumed for biomass eaten calculation that hair of adult wild boar represented yearlings only.

Grass and leaves or needles (beech, fir, spruce), not digestible to wolves, were not considered food in the analyses, although grass at least may be ingested intentionally.

\section{Results}

Cervids (red and roe deer) were the most important food of wolves in every seasons (Table 2). Red deer dew claws were found in 14 scats and roe deer in 4 . Based on this, roe deer biomass can be estimated to make up $4.5 \%$ of total Cervidae biomass consumed by wolves. Volume of cervid remains was about twice lower in winter then in other seasons (Table 2) and these differences were statistically significant (Table 4). Also estimated deer (both red and roe) biomass eaten were $20-30 \%$ lower in winter then in other seasons (Table 2 ). It was only possible to distinguish hair of fawns and adults in scats deposited in summer (Table 3). The volume of fawn remains constituted $54.5 \%$ of total identified as adult or fawn cervid 
Table 2. Composition of wolf diet - mean percent volume (V\%) of food remains found in scats and percent biomass consumed (B\%) - in the Bieszczady Mts. $n$ - number of scats.

\begin{tabular}{|c|c|c|c|c|c|c|c|c|}
\hline \multirow[t]{2}{*}{ Item } & \multicolumn{2}{|c|}{$\begin{array}{l}\text { Spring } \\
n=36\end{array}$} & \multicolumn{2}{|c|}{$\begin{array}{c}\text { Summer } \\
n=58\end{array}$} & \multicolumn{2}{|c|}{$\begin{array}{c}\text { Autumn } \\
n=26\end{array}$} & \multicolumn{2}{|c|}{$\begin{array}{l}\text { Winter } \\
n=101\end{array}$} \\
\hline & V\% & B\% & V\% & B\% & V\% & B\% & V\% & B\% \\
\hline Cervids & 79.6 & 90.8 & 89.8 & 96.0 & 91.5 & 85.3 & 44.6 & 64.9 \\
\hline Wild boar & 9.2 & 5.7 & 1.7 & 0.7 & 4.6 & 2.7 & 40.3 & 17.4 \\
\hline Cattle/horse & - & - & - & - & 3.9 & 12.0 & 2.8 & 13.4 \\
\hline Sheep & 5.6 & 2.5 & 3.4 & 2.0 & - & - & 4.4 & 2.5 \\
\hline European hare & - & - & 3.4 & 0.9 & - & - & 2.0 & 0.5 \\
\hline Voles & 5.6 & 1.0 & 1.7 & 0.4 & - & - & 5.6 & 1.2 \\
\hline Mole & - & - & - & - & - & - & 0.3 & 0.1 \\
\hline
\end{tabular}

Table 3. Relative volumes of remains of juvenile ( $<1$ year old) and adult ( $>1$ year old) ungulates found in wolf scats from the Bieszczady Mts. Ad. - adult, Juv. - juvenile, Und. - undetermined.

\begin{tabular}{|c|c|c|c|c|c|c|c|c|c|c|c|c|}
\hline \multirow{2}{*}{ Taxa } & \multicolumn{3}{|c|}{ Spring } & \multicolumn{3}{|c|}{ Summer } & \multicolumn{3}{|c|}{ Autumn } & \multicolumn{3}{|c|}{ Winter } \\
\hline & Ad. & Juv. & Und. & Ad. & Juv. & Und. & Ad. & Juv. & Und. & Ad. & Juv. & Und. \\
\hline Cervids & - & - & 28.7 & 20.0 & 24.0 & 8.0 & - & - & 23.8 & - & - & 45.1 \\
\hline Wild boar & 2 & 1 & 0.3 & - & 1 & - & 1.2 & - & - & 5 & 16 & 19.7 \\
\hline
\end{tabular}

Table 4. Comparison between sum of relative volumes of particular food categories by seasons $\left(\chi^{2}\right.$-test). $\mathrm{S}$ - Spring, Su - Summer, A - Autumn, W - Winter, ns - not significant.

\begin{tabular}{lcccccc}
\hline Food item & $\mathrm{S}-\mathrm{Su}$ & $\mathrm{S}-\mathrm{A}$ & $\mathrm{S}-\mathrm{W}$ & $\mathrm{Su}-\mathrm{A}$ & $\mathrm{Su}-\mathrm{W}$ & $\mathrm{A}-\mathrm{W}$ \\
\hline Cervids & $\mathrm{ns}$ & $\mathrm{ns}$ & $p<0.001$ & $\mathrm{~ns}$ & $p<0.001$ & $p<0.001$ \\
Wild boar & $\mathrm{ns}$ & $\mathrm{ns}$ & $p<0.001$ & $\mathrm{~ns}$ & $p<0.001$ & $p<0.001$ \\
Livestock & $\mathrm{ns}$ & $\mathrm{ns}$ & $\mathrm{ns}$ & $\mathrm{ns}$ & $\mathrm{ns}$ & $\mathrm{ns}$ \\
Other & $\mathrm{ns}$ & $\mathrm{ns}$ & $\mathrm{ns}$ & $\mathrm{ns}$ & $\mathrm{ns}$ & $\mathrm{ns}$ \\
\hline
\end{tabular}

remains in this season. The biomass of fawns eaten was estimated at $28.4 \%$ of total biomass of cervids consumed in summer.

Wild boar was the second most important food (Table 2). The wild boar remains occurred almost exclusively in winter scats (Table 2). The estimated biomass of wild boar constituted a significant portion (17.8\%) of wolf diet only in winter (Table 2 ). The piglet and adult wild boars remains could be distinguished in every seasons (Table 3). Piglets remains prevailed among wild boar and constituted $73.1 \%$ of total remains identified as adult or juvenile wild boar in the whole year and $76.2 \%$ 
in winter time. Biomass of piglets eaten constituted $60.0 \%$ of total wild boar biomass consumed during the whole year and $66.5 \%$ during winter.

Livestock (cattle/horse and sheep) were found in every seasons but more frequently in winter scats (Table 2), although the difference was statistically not significant (Table 3). During cold seasons (autumn and winter) the livestock flesh was available only as carrion placed to bait wolves by hunters. Livestock is kept in stables during those seasons. Estimated livestock carrion biomass consumed was an important food in winter (15.9\%) and autumn $(12.0 \%)$. In spring and summer the livestock remains were represented only by sheep whose estimated biomass consumed was very small (Table 2).

Other prey species were European hares Lepus europeus, voles Microtus sp., and moles Talpa europea. These prey species played a negligible part in the wolf diet (Table 2), and did not vary significantly by seasons (Table 4).

Generally the spring, summer and autumn diets did not differed significantly for the presence of any food category. But winter diet was significantly different from other seasons because of different contribution of wild boars and cervids (Table 4).

\section{Discussion}

The red deer make up $64 \%$ of total estimated ungulate number in the study area, roe deer make up 20\%, wild boar - $15 \%$ and European bison - only $1 \%$ (State Forest Administration of Krosno Forestry District unpubl. data of game inventories 1991, Bieszczady National Park Administration unpubl. data of game inventories 1991). Thus the red deer prevalence in wolf diet is not surprising. The proportion of roe deer to red deer dew claws found in wolf scats $(1: 3.2)$ is very close to the proportion of roe deer to red deer number in free living population (1:3.5) what suggest similar vulnerability of these two species to wolf predation. Cervids (both red and roe deer) were the most important food in summer when newborn fawns contributed approximately $28 \%$ to wolf diet. Such switch to newborn calves or fawns in summer is well documented. For example Fuller and Keith (1980) reported from Alberta (Canada) that during summer moose calves made up $11.7 \%$ and adults $84.3 \%$ of biomass consumed by wolves. Similar results are presented by Ballard et al. (1987) from Alaska where moose adults constituted $67.7 \%$ and calves $20.7 \%$ of summer wolf diet. Jędrzejewski et al. (1992) reported that juvenile cervids made up 55\% of total number of Cervidae killed by wolves in summer in the Białowieża National Park (eastern Poland). High vulnerability of red deer fawns to wolf predation during winters was reported earlier from the study area by Okarma (1991) and Bobek et al. (1992b).

In the Bieszczady Mountains wild boar are almost exclusively preyed by wolves during winter. Deep snow cover which lasts during winter in the mountains may be main factor increasing vulnerability of wild boars to wolf predation. In summer, wild boar constituted only a negligible part of wolf diet what reflecting a compara- 
tively low population density of this ungulate species. Wolves in the study area among wild boars selected piglets. These results agreed fully with results obtained from Slovakian Carpathians by Brtek and Voskar (1987). Wild boar piglets constituted $80 \%$ of wild boar killed by wolves there. Jędrzejewski et al. (1992) reported, on the basis of scat analysis, that in the Białowieża National Park piglets constituted $94 \%$ of wild boars killed by wolves. In central Europe adult wild boars may exceed body weight of $300 \mathrm{~kg}$ (Fruziński 1992) and due to their active defense behaviour they are difficult prey to wolves. Usually in regions were wolves occur along the wild boar and the red deer, they tend to prey on the latter ungulate species (see Jędrzejewski et al. 1992).

Livestock was a more significant food item only in winter and autumn. Because domestic ungulates are kept inside stables and barns for winter time this food was accessible only as carrion from baiting places. Large amounts of bait in wolf stomachs during winter in the Bieszczady Mountains was reported earlier by Leśniewicz and Perzanowski (1989) but due to the hunting technique (wolves are often harvested next to the baiting places) the importance of this food category was probably overestimated. Two factors could affect small contribution of livestock in summer diet: (1) sheep and cattle grazing on pastures are under permanent watch of guarding dogs and people, and (2) high density of wild ungulate species is sufficient to support the wolf population.

Other prey species as hares, small rodents and insectivores represent a negligible part in wolf diet. The presence of small mammals in wolf diet is a well known fact, but this food category plays usually a minor role (Fuller and Keith 1980, Fritts and Mech 1981, Ballard et al. 1987, Jędrzejewski et al. 1992)

No remains of the European bison in wolf scats from the Bieszczady Mountains were found. Research conducted in eastern Poland (Jędrzejewski et al. 1992) support conclusion that wolves do not attack European bison when smaller ungulates are available in number.

The results of our study show that in the Bieszczady Mountains wolves mostly feed on wild ungulates and they are independent from anthropogenic sources of food, although during hunting season (autumn and winter) carrion of domestic ungulates laid out as a bait provide a supplemental source of food.

Acknowledgements: We are grateful to R. Gula, W. Frąckowiak, G. Harna and J. Wajda who helped the senior author to collect materials in the field, to $\mathrm{Dr} \mathrm{R}$. Tertil for improving the language, and to Dr B. Bobek for his critical comments on earlier drafts of the manuscript.

\section{References}

Ballard W. B., Whitman J. S. and Gardner C. L. 1987. Ecology of an exploited wolf population in south-central Alaska. Wildl. Monogr. 98: 1- 54.

Bjarvall A. 1983. Scandinavia's response to a natural repopulation of wolves. Acta zool. Fenn. 174: $273-275$.

Bobek B., Morow K., Perzanowski K. and Kosobucka M. 1992a. Red deer (Cervus elaphus) - its ecology and management. Wydawnictwo Swiat, Warszawa: 1 - 200. [In Polish] 
Bobek B., Perzanowski K. and Śmietana W. 1992b. The influence of snow cover on the patterns of selection within red deer population by wolves in Bieszczady Mountains, Poland. [In: Global trends in wildlife management. B. Bobek, K. Perzanowski, and W. Regelin, eds]. Trans, 18th IUGB Congress, Kraków 1987, Świat Press, Kraków - Warszawa Vol. 2: 341 - 348.

Brtek E. and Voskar J. 1987. Feeding biology of the wolf in Slovak Carpathians. Biologia, Bratislawa 42: 985 - 990. [In Slovakian with English and Russian summary]

Dziurdzik B. 1973. Key to the identification of mammal hairs from Poland. Acta zool. cracov. 18: 73 - 91. [In Polish]

Floyd T. J., Mech L. D. and Jordan P. A. 1978. Relating wolf scat content to prey consumed. J. Wildl. Manage. 42: 528 - 532 .

Fritts S. H. and Mech L. D. 1981. Dynamics, movements, and feeding ecology of a newly protected wolf population in northwestern Minnesota. Wildl. Monogr. 80: 1 - 79 .

Fruziński B. 1992. [Wild boar]. Wydawnictwo Cedrus, Warszawa: 1-248. [In Polish]

Fuller T. K. and Keith L. B. 1980 . Wolf population dynamics and prey relationships in northern Alberta. J. Wildl. Manage. 44: 583 - 602 .

Gabis J., Botto V. and Sidor V. 1975. Atlas of farm animals. National Agriculture and Forestry Publ., Warszawa: $1-393$.

Hayes R. D., Bear A. M. and Larsen D. G. 1991. Population dynamics and prey relationships of an exploited and recovering wolf population in the southern Yukon. Yukon Fish and Wildlife Branch Final Report TR-91-1: 1 - 67.

Jędrzejewski W., Jędrzejewska B., Okarma H. and Ruprecht A. L. 1992. Wolf predation and snow cover as mortality factors in the ungulate community of the Białowieza National Park, Poland. Oecologia 90: 27 - 36 .

Leśniewicz K. and Perzanowski K. 1989. Winter diet of wolves in Bieszczady Mountains. Acta theriol. 34: $373-380$

Meriggi A., Rosa P., Brangi A. and Matteucci C. 1991. Habitat use and diet of wolf in northern Italy. Acta theriol. 36: $141-151$.

Michna E. and Paczos S. 1972. Zarys klimatu Bieszczad Zachodnich. Ossolineum, Wrocław: 1 - 72. [In Polish]

Nieminen M. and Leppaluoto J. 1988. Predation in the reindeer husbandry area in Finland during 1976 - 1986. Rangifer 8: $25-34$.

Okarma H. 1991. Marrow fat content sex and age of red deer killed by wolves in winter in the Carpathian Mountains. Holarctic Ecol. 14: 169 - 172.

Pielowski Z. 1988. Roe deer. National Agliculture and Forestry Publ., Warszawa: 1 - 293. [In Polish]

Pucek Z. (ed) 1984. [Key for identification of Polish mammals]. PWN - State Sci. Publisher, Warszawa: 1 - 384. [In Polish]

Salvador A. and Abad P. L. 1987. Food habits of a wolf population (Canis lupus) in Leon Province, Spain. Mammalia 51: $45-52$

Sumiński P. and Filipiak W. 1977. Contribution to the investigation into the feeding of the wolf (Canis lupus L.). Z. Jagdwiss. 23: 1 - 5. [In German with English and French summary]

Weaver J. L. and Hoffman S. W. 1979. Differential detectability of rodents in coyote scats. J. Wildl. Manage. 43: 783 - 789

Received 13 March 1993, accepted 9 July 1993. 